\title{
The Needs of Students in Saudi Arabia Seeking to Study in Japan: A Poll-Survey Analysis
}

\author{
Hiroko Kinoshita ${ }^{1}$ \\ ${ }^{1}$ Associate Professor, Kyushu University, Japan \\ Correspondence: Hiroko Kinoshita, Associate Professor, Kyushu University, Japan
}

Received: June 23, 2019

Accepted: July 18, 2019

Online Published: July 25, 2019

doi:10.5430/ijhe.v8n4p145

URL: https://doi.org/10.5430/ijhe.v8n4p145

\begin{abstract}
This study attempts to bridge the gap in the research for students in Saudi Arabia going abroad to study. While there is research done in the field of higher education in Western countries, or even students who have reached Japan for future studies, very few study have tried to investigate the issue such a study for Saudi Arabians before they shift to Japan. Thus this research focused on prospective students to understand their intention and their needs for information on studying in Japan though a poll survey.

Through examined both descriptive statistics and used a regression model on its survey data, the results revealed that respondents had extremely high expectations about studying in Japan, especially for obtaining degree (bachelor, master and Ph.D.). However, the regression analysis showed that even though their interests for studying in Japan were high, the information they need were only very basic, such as research facilities and admissions and requirements. This indicated that the students in Saudi Arabia had not reached a level of interest in which they required detailed information on studying in Japan. Although an Increasing number of students are choosing to study abroad in Japan in these days, thus indicating the prospects of future developments in this area.
\end{abstract}

Keywords: international student mobility, Middle East, Saudi Arabia, higher education, poll survey

\section{Introduction}

Saudi students who seek to study abroad typically choose North American or European destinations yet these students rarely choose Asian countries, such as Japan (Ministry of Higher Education, Kingdom of Saudi Arabia [MHEKSA], 2019) The literature discussing Saudi international students as they adjust to new societies and cultures while studying abroad is relatively new (Lefdahl-Davis \& Perrone-McGovern, 2015; Alsahafi \& Shin, 2017). Survey-based studies have also recently explored scholarships and decision-making among the Kingdom's graduate students (Hilal, Scott \& Maadad, 2015; Altuwaijri, 2018; Yakaboski, Perez-Velez \& Almutairi, 2017). Since there are relatively few Saudi international students studying in Japan when compared to those in North America and Europe, little is known about their specific mobility. However, researchers from a Japanese university that accepts large numbers of Saudi students have examined the related human network by tracking student life (Taguchi, 2017). Takeuchi and Aoki also focused on supplement support for Saudi students studying at their university. They suggested the creation of an environment in which Saudi and Japanese students could more easily communicate (Takeuchi \& Aoki, 2017).

Most studies on Saudi international students in Japan have examined the nature of their support networks after entering the country. Thus, little research has been conducted on their circumstances before inbounding to Japan. This study therefore focused on prospective international students living in Saudi Arabia. The study included an opinion survey from a Japanese university booth at the International Exhibition and Conference on Higher Education (IECHE) in 2019, which was the largest higher-education event in Riyadh, Saudi Arabia at the time. Students were asked questions about their visions of studying in Japan. The results were statistically analyzed to clarify respondent intentions for studying in Japan and noted the type of information they desired on the subject. A qualitative analysis was also performed.

The next section outlines international student mobility trends in Saudi Arabia by focusing on related data (e.g., destinations and scholarships). This is followed by a brief overview of IECHE, which is the largest higher-education event in Saudi Arabia. Second section includes explanation on this study's dataset and the analysis method used to analyze respondent answers about their visions of studying abroad and the information needed before doing so. 
Finally, this paper discusses these visions and the factors that may prevent students from studying in Japan.

\section{International Student Mobility and Related Trends in Saudi Arabia}

\subsection{International Mobility Among Saudi Students}

Most Saudi students who study abroad do so in the United States or EU countries. Well over 100,000 Saudi students studied in the United States in both the 2014/2015 and 2015/2016 school years (Figure 1). The ministry suddenly stopped counting international students according to their specific countries, instead using regional numbers (i.e., those from all Arab or East Asian countries). It can be assumed that the index labeled "East Asian Countries" contains those in Southeast Asia, South Asia, East Asia, and Oceania because the total number of international students exceeds 10,000 , which is similar to the total achieved when counting students studying in those regions. When those who attended EU schools are added, over $80 \%$ of the total either studied there or in the United States. Prior to 2014/2015, the ministry provided international student numbers according to specific country, thus able to determine how many students had chosen to study in Canada. However, the index labeled "United States" now probably includes Canada; this assumption is based on the total number. Notably, a 2018 diplomatic feud between Saudi Arabia and Canada prompted Saudi Arabia to instruct all Saudi students to leave Canada by the end of August of that year (Business Insider, August 26 2018). In addition, the country does not seem to send new students to Canada at this time and also no Canadian universities participated in IECHE 2019.

More than $70 \%$ of all Saudi international students have received government-sanctioned scholarships from The King Abdullah Scholarship Program (KASP) over the last decade (excluding the 2007/2008 school year) (MHEKSA, 2019). The number of students receiving the KASP has increased tenfold over this period (it should also be noted that the number of self-sponsored students has increased eightfold).

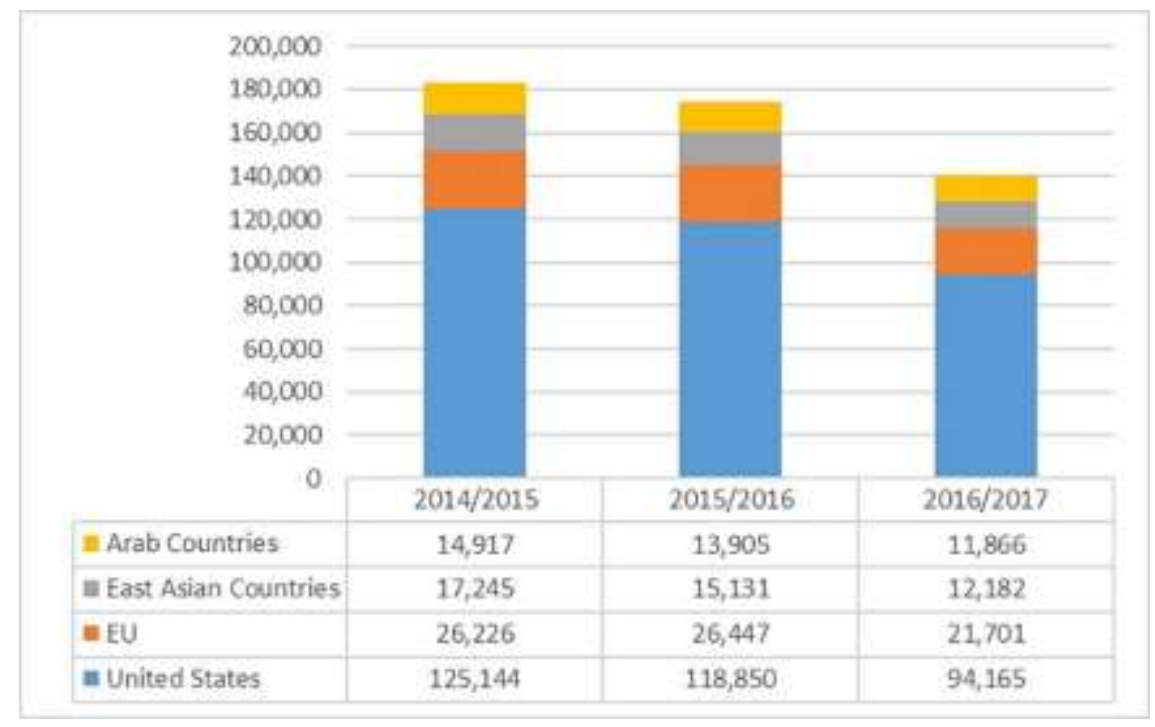

Figure 1. Number of Saudi international students by region

\section{Source: The Ministry of Education, Kingdom of Saudi Arabia}

Based on data from 2011, Smith and Abdulrahmanm found that approximately $85 \%$ of Saudi students studying at international universities were funded by the KASP. The money was used to cover travel expenses, tuition, and living costs for these students as well as the needs of their accompanying family members (e.g., wives/husbands and/or children). Popular destinations for students leaving the Middle Eastern region include the United States, United Kingdom, Canada, and Australia, while Egypt and Jordan are popular countries for those choosing to study in neighboring states (Smith \& Abdurlahman, 2013).

The KASP is administrated by The Saudi Arabian Cultural Mission in each respective destination country. While the KASP provides many opportunities for Saudi students who are studying abroad, there are various restrictions. Some studies (Perna et al., 2014; Yakaboski, Perez-Velez \& Almutairi, 2017) have found that the Saudi government strictly evaluates the degree types and faculties chosen by these students. Students wishing to study in Japan must choose from 200 approved universities that are available on an official government list. The KASP also requires students to study the predominant language in their country of choice. Thus, students who select the United States, United 
Kingdom, or Asian countries such as Singapore and India must study in English. Although the KASP involves restrictions, it still provides many opportunities for Saudi students who seek educations abroad.

While most Saudi international students seek to study in the United States or EU countries, the number of those choosing Japan notably increased since 2008/2009. In academic year 2008/2009, there were only 153 Saudi students in Japan and then it reached nearly 750 students in year 2013/2014 (MHEKSA, 2019). This increase in number suggests, despite the language barrier, Japan is gradually recognized in the study abroad market in Saudi Arabia.

\subsection{Overview of the International Exhibition and Conference on Higher Education (IECHE)}

The International Exhibition and Conference on Higher Education (IECHE) is the largest convention for higher education in Saudi Arabia. With some exceptions, it has been held annually since 2010. There is a new theme each year; this year, the government used "Transforming Saudi Universities in an Era of Change." Past themes included "The First Conference" (2010), "Leading Worlds' Universities System" (2011), "Leading World Teaching University" (2012), "Social Mission of the Universities" (2013), "Innovation in the Higher Education" (2014), "University of the 21 st Century" (2015), and "Saudi Universities and 2030 Vision-Knowledge is Oil of the Future" (2017) (IECHE Daily Bulletin Issue 1: 13). The event was cancelled in 2016 and 2018. While not specifically stated, this was likely due to political instability. As far as we can see from the themes, Saudi government has strong motivation to play core role for leading the higher education in the world.

The IECHE official daily bulletin stated that there were 372 exhibitors, 300 international universities and other higher-education institutions, 72 local Saudi universities and other educational institutions, and 29 countries represented in 2019 (IECHE Daily Bulletin Issue 2: 11). This was nearly the same size as the 2017 event. Among those participating were 83 institutions from the United States (the largest representation this year), 75 from the United Kingdom, 26 from Australia, and 11 from France. The Saudi government also invited a number of institutions from Asian countries, including Malaysia (7), Korea (6), Japan (6), China (4), Singapore (2), and the Philippines (1). Exhibitors catered to university and high school students who were interested in studying abroad. These students typically looked for information on universities both inside and outside Saudi Arabia.

The United States, United Kingdom, and Australia were the most prominent participants. This reflected the interests of international outbound students in Saudi Arabia. The United States is still the most popular destination for Saudi international students, with many being automatically selected and sent there by The Saudi Arabian Cultural Mission (Note 1). However, many institutional representatives from the United States still visited IECHE 2019 to recruit Saudi students.

As discussed in previous section, only about one-ninth the amount of Saudi students studying in the United States choose Asian countries (half the number choosing the United Kingdom). Here, Japan is very popular. It can thus be said that Japan is becoming an increasingly important destination. This study therefore clarified and analyzed the type of information needed by students at the event who were considering Japan. While IECHE is a very large event authorized by the Saudi Kingdom, all visitors were registered and identified. Visitors to the Japanese university booth were thus considered appropriate respondents.

\section{Data Collection and Analysis}

\subsection{Overview of Respondents}

The author conducted an online survey over a four-day period (April 10-13 of 2019). IECHE 2019 was held at Riyadh. While the total number of participants was not reported, there were approximately 142,000 in 2017 (a record at that time). Visitors were asked to access the questionnaire by using a website link and proceeded to answer the questions. Of the total 584 respondents, 68\% $(n=398)$ were male and $32 \%(n=186)$ were female.

Most respondents were Saudi citizens $(63 \%(\mathrm{n}=370))$. This was followed by those from Middle Eastern countries $(25 \%(\mathrm{n}=144))$, Asia Pacific $(6 \%(\mathrm{n}=37))$, African countries $(4 \%(\mathrm{n}=22))$, and Europe and North America (2\% $(\mathrm{n}=11)$ ). There were 536 total visitors from the Middle East and Africa (including Saudi Arabia), thus comprising more than $90 \%$ of the total. Syrian and Jordanian citizens comprised most of those from the Middle East. Those from African countries were either Egyptian or Sudanese. Students including both university and high school were the biggest affiliation of the respondent $(n=400)$. Respondents from Asia Pacific and Europe and North America were student-parents working in Saudi Arabia; their children were either born in Saudi Arabia or one of those countries.

A total of $99 \%(n=579)$ of all respondents were interested in studying in Japan, while $1 \%(n=5)$ were not. Visitors who answered "No" to this item also classified their jobs as "Others"; some said they were agents who worked to send students to foreign countries, and thus were not personally interested in studying in Japan. 
The questionnaire divided study-abroad programs into several categories (i.e., Master and Ph.D., Undergraduate Degree, Other, Short Term Program (e.g., Summer Course), and Short Term Exchange (up to 1 year)). Respondents were asked to choose one program they were interested in the most. Degree programs (including Master and Ph.D. and undergraduate level programs) were the most popular $(85 \%(\mathrm{n}=501))$. Respondents who answered "Others" did not clarify or mention a specific preference, while those interested in short term programs/exchanges only represented 5.7\% $(n=33)$. Degree programs were thus statistically the most popular. This also reflected some of the narratives provided by parents of Saudi high school students, as follows:

"We want to send [our] son abroad to provide him a good education in a good environment and want him to obtain a Master's and Ph.D." (Note 2)

A Sudanese student who was born in Saudi Arabia and lived in Riyadh also stated interest in a degree program, as follows:

"If I could get Master's or Ph.D. abroad I think I can get good job here or in another country."

(Note 3)

The last questionnaire item "What type of information is the most important if you are going to study in Japan?" was asked to determine what information respondents valued when considering studying in Japan or what they were most concerned about in regard. The most frequent answer was "information on research facilities" (nearly $50 \%$ of the total $(n=259))$. One of the university students who answered the questionnaire added that he had no idea what Japanese universities were like because none of his friends were studying in Japan or wanted to go there for study; he thus wanted to know more about Japanese research facilities and laboratory equipment (Note 4). Another respondent wanted to know whether she could get Japanese language support while studying in Japan (Note 5). The second most frequent responses indicated that students wanted information about admissions and requirements. In addition, the Japanese academic calendar usually starts in April and ends in March. Respondents who were studying in Saudi Arabia (both Saudi and other citizens) were not used to this. Most verbal responses to questions about admissions and requirements were about the timing or suitable months to send applications and the type of certificates required when applying. One respondent who was studying at an international high school stated the following:

"I am studying under the same curriculum used in the United States. What are the entrance examination requirements? Is my high school certificate accepted? I want to know about the admissions process in Japan because all I know about is the system in the United States." (Note 6)

Information on scholarship, daily life in Japan and the way to find supervisor in Japan seem not popular and necessary among the respondents.

The descriptive statistics indicated that degree programs were much more popular than short-term programs; respondents believed that the two most important factors when thinking about studying in Japan were university research facilities and admission requirements. Figure 2 shows descriptive statistics value based on survey data.

\begin{tabular}{llllll} 
Variable & Obs & Mean & Std. Dev. Min & Max \\
\hline & 584 & 0.857877 & 0.349476 & 0 & 1 \\
formal_prog & 584 & 0.409247 & 0.492116 & 0 & 1 \\
univ_st & 584 & 0.275685 & 0.447242 & 0 & 1 \\
high_st & 584 & 0.164384 & 0.370941 & 0 & 1 \\
parents & 584 & 0.070206 & 0.255712 & 0 & 1 \\
staff & 584 & 0.633562 & 0.482244 & 0 & 1 \\
Saudi & 584 & 0.318493 & 0.466291 & 0 & 1 \\
q1 & 584 & 2.594178 & 0.791052 & 1 & 4 \\
most_impor 0 & 584 & 0.037671 & 0.190563 & 0 & 1 \\
Africa & & & &
\end{tabular}

Figure 2. Descriptive statistics value

Source: Made by the author based on survey data 


\subsection{Analysis}

This section discusses program interest and the most important information students believe they need when studying in Japan. First, degree programs (both undergraduate and post-graduate) are much more popular than others. The next step in this analysis was cross tabulation. Specifically, several tabulations were implemented to determine mutual relationships between factors. First the relationship between occupation and program is considered. The result is visualized in Figure 3. The evidence clearly indicated that university students were more interested in graduate programs, while high school students were more interested in undergraduate programs. Answers from respondents working at universities in MENA countries and those identifying as study-abroad agents (categorized as other) were generally unbiased. These respondents showed interest in each program even though student respondents did not want information on short-term programs.

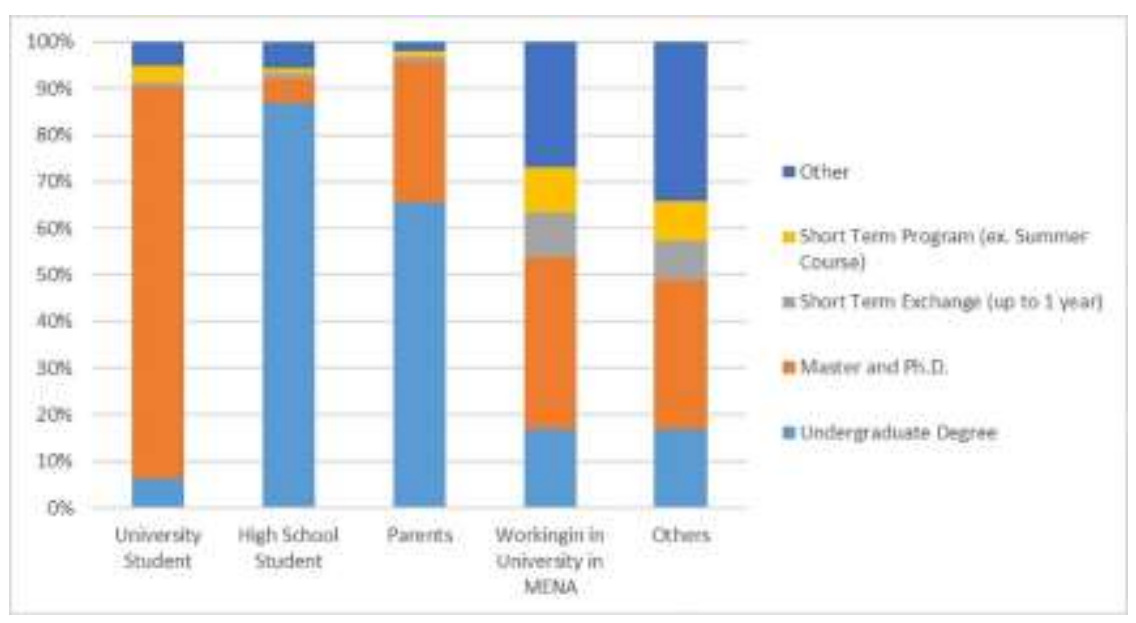

Figure 3. Cross-tabulation results (occupation and program)

Source: Made by the author based on survey data

These factors were also analyzed statistically. That is, responses from those who were interested in degree programs were submitted to a logistic regression model. Dependent variables consisted of respondents who were interested in degree programs (both undergraduate degrees and Master and Ph.D. programs). The model was intended to clarify which respondents were interested in degree programs as well as the determining factors for choosing specific program types.

Results indicated that university students, high school students, and student parents were interested in degree programs over other types (statistically highly significant). In other words, these respondents were more likely to have interest in formal degree programs (Figure 4).

\begin{tabular}{|c|c|c|}
\hline & Coef & Stad. Err \\
\hline University Student & $2.436844 \cdots$ & 0.3839168 \\
\hline High School Student & $2,682192 \cdots$ & 0.4420263 \\
\hline Parents & $3.295485 \cdots$ & 0.6110295 \\
\hline Workingin in University in MENA & 0.2867549 & 0.4362182 \\
\hline Saudi Arabian & 0.0467087 & 0.2923515 \\
\hline Sex & -0.4491395 & 0.3024186 \\
\hline (Constant Term) & -0.0595644 & 0.3671401 \\
\hline Number of Observation & \multicolumn{2}{|l|}{584} \\
\hline$x^{2}$ & \multicolumn{2}{|l|}{82.91} \\
\hline Log Likelihood & \multicolumn{2}{|c|}{-197.28397} \\
\hline Pseudo R2 & \multicolumn{2}{|c|}{0.1736} \\
\hline$* p<0.1 \cdots p<0.05 \cdots p<0.01$ & & \\
\hline
\end{tabular}

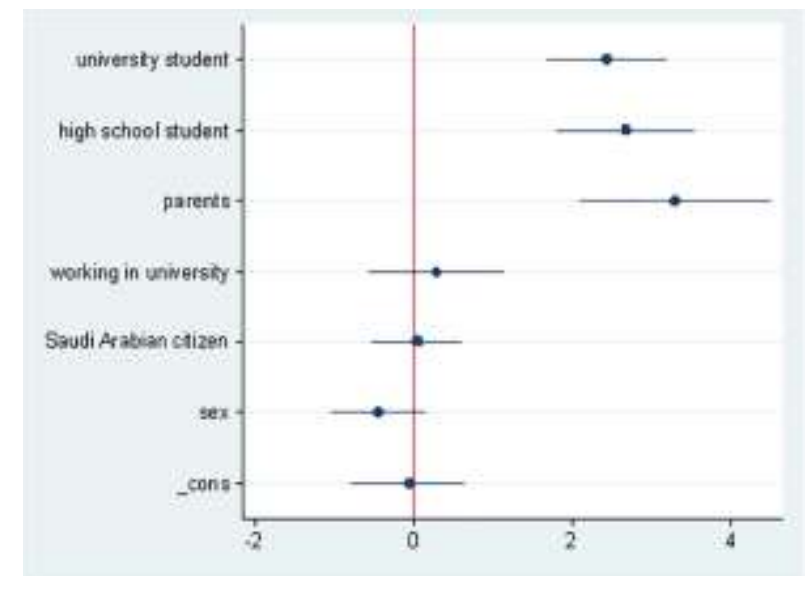

Figure 4. Determining factors for interest levels in certain degree programs and the marginal effect Source: Made by the author based on survey data 
The second most important factor was the type of information needed when studying in Japan. As discussed in previous section, information on research facilities (laboratory environments and admissions and requirements) were regarded as highly important. Another cross-tabulation results visualized in Figure 4 indicate that Saudi respondents regarded research facilities and Japanese university environments as the most important issues, while information on scholarships, daily life in Japan, and matching with a supervisor were much less important. Respondents from African countries tended to think that information about scholarships and Japanese research facilities was most important.

When processing the statistical data, the dependent variables were prepared in the following manner: Answers were recoded as 1) Scholarship, 2) Information on research facilities, 3) Admissions and requirements, and 4) Others. The independent variables consisted of the following dummy variables: Degree Program (respondents who selected the answer "Master and Ph.D. program" or "Undergraduate degree"), University Student, Working at MENA University, Saudi Arabian, African Countries, and Sex. A multinomial logit model regression was then implemented to clarify which factors (independent variables) were affected when respondents chose the information they believed was most important (dependent variables). The results are shown in Figure 5.

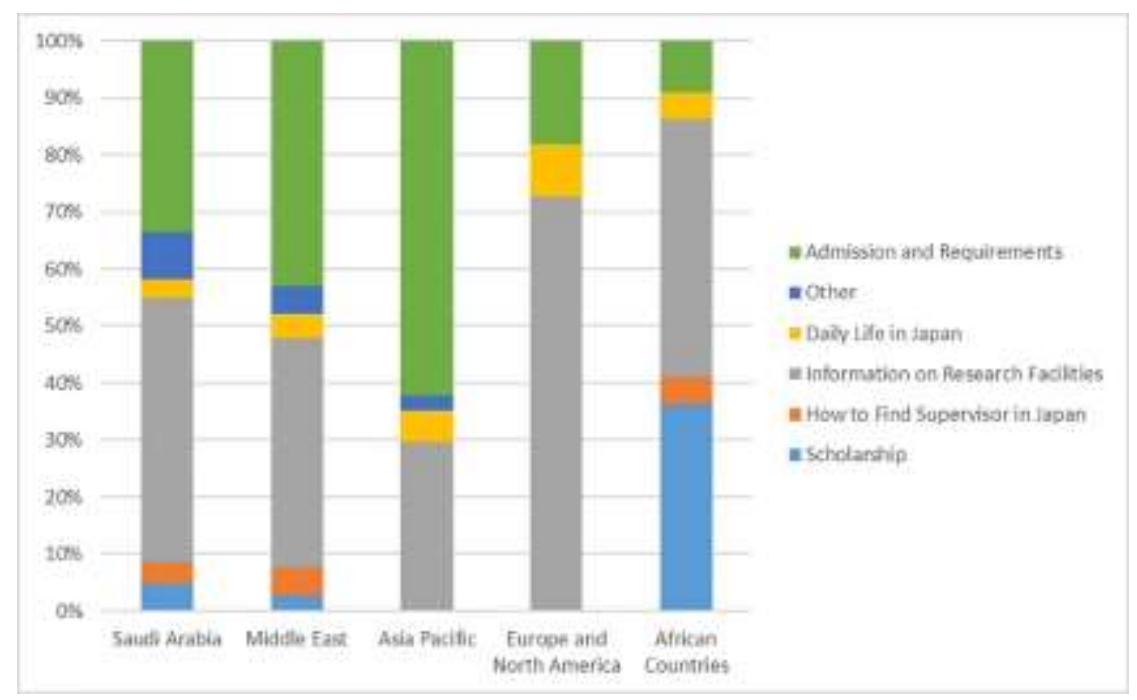

Figure 5. Cross-tabulation results (nationality and most important information)

Source: Made by the author based on survey data

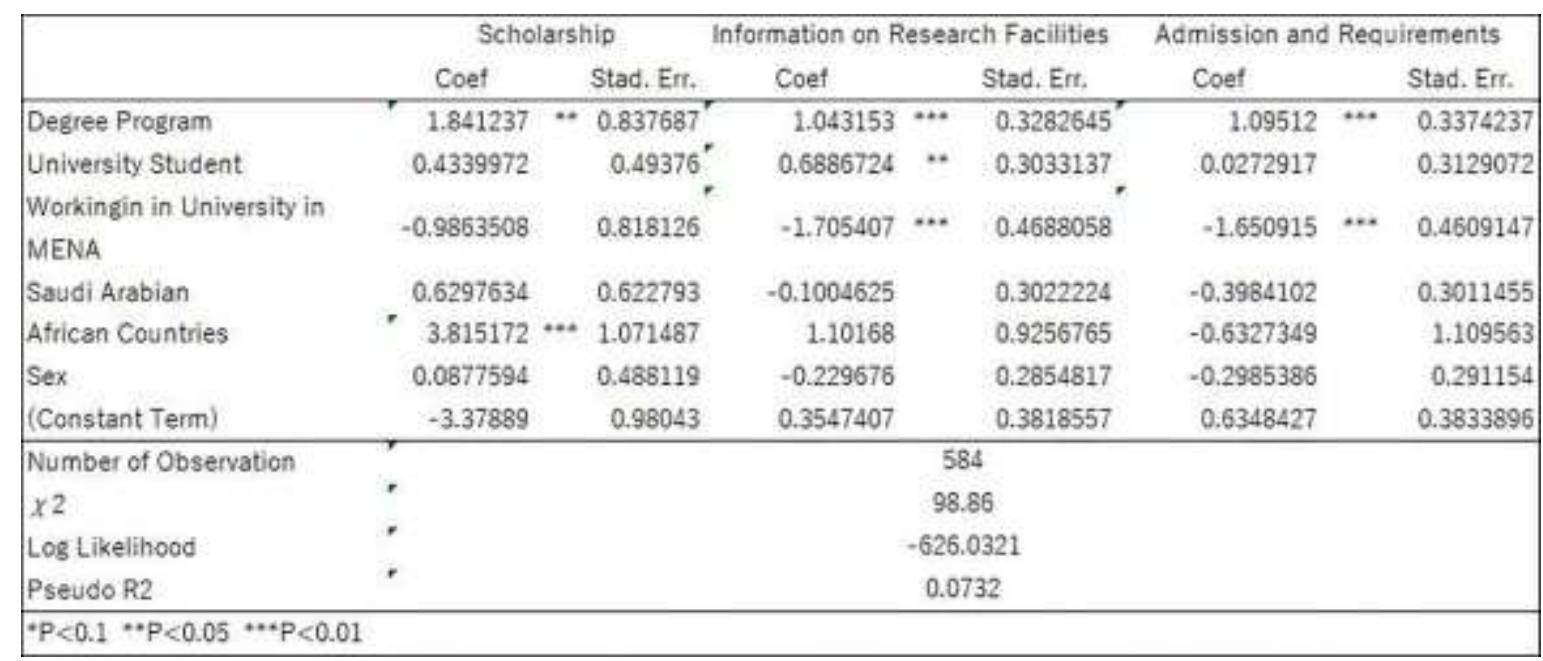

Figure 6. Determining factors for what information was needed by whom (reference category: other)

Source: Made by the author based on survey data 
The result of multinomial logit model regression (Figure 6) shows that Scholarships had positive values for African Countries and Degree Program, hence respondents from African countries and those interested in degree programs were more likely to regard scholarship information as the most important type. Research facilities had positive values for Degree Program and University Student. Respondents who were university students and interested in degree programs tended to think information about research facilities was the most important type. However, respondents working at MENA universities were less likely to place importance on this information. Information on admissions and requirements reflected similar results. The Degree Program variable was positive, while working at a MENA university was negative. Those interested in degree programs placed substantial importance on information about admissions and requirements.

\section{Conclusion}

This study examined both descriptive statistics and used a regression model on its survey data. Results revealed the fact of how visitors envisioned studying abroad in Japan and what information they needed when considering doing so. An overview of the descriptive statistics from the survey data analysis indicated that respondents had extremely high expectations about studying in Japan. Respondents specifically showed great interest in degree programs (both undergraduate and post-graduate), thus highlighting the emphasis placed on obtaining a degree if choosing to study abroad.

However, the regression analysis indicated that even those with great interest in studying in Japan only required very basic information. Those interested in degree programs wanted information on laboratory environments, curricula, research facilities, and admissions and requirements. This indicates a superficial level of interest about studying in Japan. These respondents had not reached a level of interest in which they required detailed information. Studying abroad in the context of Saudi Arabia is likely similar to how studying abroad is viewed in the United States and EU countries. However, an increasing number of students are choosing to study abroad in Japan, thus indicating the prospect of future developments in this area.

\section{References}

Alsahafi, N., \& Shin, S. (2017). Factors Affecting the Academic and Cultural Adjustment of Saudi International Students in Australian Universities. Journal of International Students, 7(1), 53-72. https://doi.org/10.32674/jis.v7i1.245.

Business Insider. (2018, August 26). Thousands of Saudi Arabian students have to leave Canada because their governments are fighting, so they're frantically selling their furniture and cars. Retrieved May 7, 2019 from: https://www.businessinsider.com/saudi-students-sell-cars-furniture-forced-to-leave-canada-feud-2018-8.

IECHE Daily Bulletin Issue 1. Retrieved from http://www.ieche.com.sa/english/download-center

IECHE Daily Bulletin Issue 2. Retrieved from http://www.ieche.com.sa/english/download-center

IECHE Daily Bulletin Issue 3. Retrieved from http://www.ieche.com.sa/english/download-center

IECHE Daily Bulletin Final. Retrieved from http://www.ieche.com.sa/english/download-center

Hausmann, R., Tyson, L. D., \& Zahidi, S. (2009). The global gender gap report 2009. Geneva, Switzerland: World Economic Forum.

Hilal, Khoooud T., Scott, Safiyyah R. \& Maadad Nina. (2015). The Political Socio-economic and Sociocultural Impacts of the King Abdullah Scholarship Program (KASP) on Saudi Arabia International Journal of Higher Education, 4(1), 254-267. https://doi.org/10.5430/ijhe.v4n1p254

Larry, S., \& Abdulrahman, A. (Eds.). (2013a). Higher Education in Saudi Arabia: Achievements, Challenges and Opportunities, Springer, Dordrecht.

Larry, S., \& Abdulrahman A. (2013b). Higher Education in Saudi Arabia: Reforms, Challenges and Priorities. In Larry, S., \& Abdulrahman, A. (Eds.), Higher Education in Saudi Arabia: Achievements, Challenges and Opportunities, (pp.1-12). Springer, Dordrecht.

Lefdahl-Davis., Erin M., Perrone-McGovern., \& Kristin M. (2015). The Cultural Adjustment of Saudi Women International Students: A Qualitative Examination. Journal of Cross-Cultural Psychology, 46(3), 1-29. https://doi.org/10.1177\%2F0022022114566680.

Lolwah, A. (2018). Dispute over the King Abdullah Scholarship Program. Open Journal of Social Science, 6, 107-118. https://doi.org/10.4236/jss.2018.66011. 
Makio, Y. (2016). Vision 2030 and the Birth of Saudi Solar Energy. Middle East Institute Policy Focus Series, July 2016, 15, 1-9.

Ministry of Higher Education Kingdom of Saudi Arabia. (2019). Higher Education Statistics. Retrieved June 3, 2019 from: https://departments.moe.gov.sa/PlanningDevelopment/RelatedDepartments/Educationstatisticscenter/Education DetailedReports/Pages/default.aspx

Mohammad, N. (2017). Transformation from an Oil-based Economy to a Knowledge-based Economy in Saudi Arabia: the Direction of Saudi Vision 2030. Journal of Knowledge and Economy, 8(2), 536-564. https://doi.org/10.1007/s13132-017-0479-8

Perna, L. W., Orosz, K., Gopaul, B., Jumakulov, Z., Ashirbekov, A., \& Kishkentayeva, M. (2014). Promoting human capital development: A typology of international scholarship programs in higher education. Educational Researcher, 43(2), 63-73. https://doi.org/10.3102/0013189X14521863

Reda, G. \& Hamdan, A.K. (2015). Gender, Language, and Society: Saudi Female University Students' Perception of the Category of Professions. Multidisciplinary Journal of Gender Studies, 4(2), 666-689. http://dx.doi.org/10.17583/generos.2015.1334.

Tamara, Y., Perez-Velez, K., \& Almutairi, Y., (2017). Collectivists' Decision-Making: Saudi Arabian Graduate Students' Study Abroad Choices. Journal of International Students, 7(1), 94-112. https://doi.org/10.32674/jis.v7i1.247.

Takeuchi, S., \& Aoki, Y. (2017). Supplemental Support for Study and Life to Saudi Arabian Students at Tokai University. Japanese Language Education Methods, 23(2), 108-109. (in Japanese)

Taguchi, K. (2014). Changes in Saudi Arabian students' human network during their study abroad: Comparing the first year and the final year of studying in Japan. Bulletin of Tokai Institute of Global Education and Research, Tokai University, 4, 105-115. (in Japanese)

UNESCO Institute for Statistics. (2009). Global Education Digest 2009. Montreal, QC: Author.

World Bank. (2008). Investment in education. In The road not traveled: Education reform in the Middle East and North Africa. Retrieved from http://go.worldbank.org/JLMVU0I6R0.

\section{Notes}

Note 1. Personal correspondence with an international recruiter from a university in the United States on April 9, 2019.

Note 2. Retrieved from personal correspondence on April 12, 2019.

Note 3. Interview with a Sudanese student while he was answering the survey on April 10, 2019.

Note 4. Personal correspondence with a Saudi university student while he answering the questionnaire on April 10, 2019.

Note 5. Personal correspondence with a high school student during her visit to the booth on April 13, 2019.

Note 6. Interview with an international high school student during his visit to the booth on April 11, 2019. 